\title{
SEQUENCING AND PHYLOGENETIC ANALYSIS OF THE INFECTIOUS BURSAL DISEASE VIRUS ISOLATES FROM OUTBREAK IN LAYER FLOCKS IN THE STATE OF MINAS GERAIS
}

\author{
Camila Cristina Almeida Dias ${ }^{1}$; Fernanda de Oliveira Souza ${ }^{1}$; Elisa Monteiro Sant'Anna da Silva ${ }^{1}$; \\ Monique Renon Eller ${ }^{1}$; Priscilla Rochele Barrios ${ }^{1}$; Bernadete Miranda dos Santos ${ }^{2}$; Mauro Pires Moraes ${ }^{1}$; \\ Márcia Rogéria de Almeida ${ }^{1 *}$
}

${ }^{1}$ Laboratório de Infectologia Molecular Animal, Instituto de Biotecnologia Aplicada à Agropecuária, Universidade Federal de Viçosa,Viçosa, MG, Brasil; ${ }^{2}$ Unidade de Ensino em Sanidade Avícola, Departamento de Veterinária, Universidade Federal de Viçosa, Viçosa, MG, Brasil.

Submitted: March 19, 2008; Returned to authors for corrections: April 07, 2008; Approved: February 25, 2009.

\section{SHORT COMMUNICATION}

\begin{abstract}
Sequencing and phylogenetic analysis based on the nucleotide sequence of the gene encoding VP2 protein was carried out in order to characterize the agent of two outbreaks of infectious bursal disease in layer flocks in the state of Minas Gerais in 2004. The results indicate the outbreaks could be related to the vaccinal virus.
\end{abstract}

Keywords: IBDV, RT-PCR, molecular characterization, phylogenic analysis, infectious bursal disease.

Infectious bursal disease (IBD) is an acute, highly contagious disease of young birds $(8,9)$. The etiologic agent, IBD virus (IBDV), infects bursal B-lymphocytes resulting in immune depression and an increase in the incidence of vaccine failures and secondary infections (8). Classical detection of IBD virus is a time-consuming and costly procedure. The application of molecular methods enables a more exact differentiation of IBDV strains, and in this case, information on the origin of the virus.

The nucleotide sequence of the hypervariable region from the VP2 protein has been described as a useful tool to characterize field isolates $(2,3,6,10)$. Also, mutations in this region, which modify the viral antigenicity and tropism (4), have been described.

Here we described the sequencing and phylogenetic analysis of isolates of IBDV in an effort to characterize two independent outbreaks in commercial layer flocks in the central region of Minas Gerais in 2004. Samples of bursae were obtained from two IBDV-vaccinated layer chicken flocks experiencing problems with immune suppression that suggested IBDV infection. The isolates LIMA0504 and LIMA0604 were obtained from a sample containing eight bursae collected from a 22-dayold flock and 30-day-old flock, respectively. In both cases, the flocks were vaccinated at 12 and 19 days of age with an intermediate plus vaccine. A live vaccine was administered via drinking water, following the manufacturer's recommendations. During the outbreaks, clinical signs such as depression, anorexia, droopy appearance, diarrhea, and dehydration were observed. The daily mortality rate was $0.5 \%$ and $1.5 \%$ respectively, and total morbidity was $80 \%$ for both outbreaks.

Histopathology of the bursa from both flocks showed different degrees of necrosis of lymphocytes in the medullary area of bursal follicles, haemorrhagic areas and interfollicular heterophilic infiltration indicating an inflammatory reaction. Additionally, the 30-day-old flock showed follicular and interfollicular oedema.

The isolation of the virus was performed in VERO cells. After two passages, the monolayer was collected and total RNA was extracted using TRIzol reagent (Invitrogen), following the manufacturer's recommendations. The oligonucleotides used for the synthesis and amplification of

*Corresponding Author. Mailing address: Av. PH Rolfs, s/n, Campus UFV, 36570-000. Viçosa, MG, Brasil. Tel.: (+5531) 3899-2911. Fax: (+5531) 3899-2864. E-mail: marcia@ufv.br 
the cDNA were built from the nucleotide sequence of the hypervariable region of VP2 protein described by Baylliss et al. (1): VP2F, 5' GTAACAATCACACTGTTCTCAG and VP2R, 5'GATGGATGTGATTGGCTGGG. Synthesis of cDNA from total RNA was carried out using primer specific for VP2 (VP2R). RNA processing was performed using the SuperScript ${ }^{T M}$ First-strand Synthesis System for RT-PCR (Invitrogen), following the manufacturer's recommendations. For the amplification of cDNA encoding the VP2 virus protein for molecular characterization of the isolates, a mixture was used consisting of $2 \mu \mathrm{L}$ cDNA, PCR buffer $1 \mathrm{X}, 5 \mathrm{mM} \mathrm{MgCl} 2,0.2 \mathrm{mM} \mathrm{dNTP}, 1 \mathrm{pmol}$ of each oligonucleotide, VP2F and VP2R, and $1 \mathrm{U}$ of Taq DNA polymerase (Invitrogen). For a negative control template, a amplification reaction was prepared using ultra-pure water. Reactions were performed in a thermocycler (MJ RESEARCH, INC - PTC 100) for 40 cycles at $94^{\circ} \mathrm{C}$ for 2 minutes, $94^{\circ} \mathrm{C}$ for $40 \mathrm{~s}, 55^{\circ} \mathrm{C}$ for 1 minute, 30 $\mathrm{s}$ and $72^{\circ} \mathrm{C}$ for 1 minute and $72^{\circ} \mathrm{C}$ for 5 minutes. PCR products were cloned using pGEM T Easy Vector System (Promega). Subsequently, purified plasmid DNAs were sequenced. The phylogenetic studies, with the MEGA 3.1 software, used the Neighbor-Joining algorithm, with the Kimura's model (5), together with the bootstrap method with 1.000 repetitions.

The phylogenetic tree developed from the nucleotide sequences showed clustering of newly IBDV isolates (LIMA0504 and LIMA0604) with classical IBDV isolates used in attenuated vaccines (Fig. 1). Furthermore, the comparison of nucleotide sequences and the deduced amino acid sequences of isolates with a vaccinal virus showed complete identity among the local isolates and high identity (98-100\%) with classical strains used in the production of Brazilian IBD vaccines (Fig. 2).

Molecular characterization of the VP2 genome region of IBDV by RT-PCR and genome sequencing is a commonly utilized approach to differentiate and classify IBDV isolates $(3,6)$. Outbreaks caused by vaccinal virus have been described worldwide $(3,7,10)$. Companies must comply with local legislation for licensing avian vaccines that includes all safety tests, these reports suggest that IBD outbreaks can occur as a result of the application of low passage vaccines. It is important that live attenuated vaccines be stable, with no tendency to revert to virulence on passage. There are vaccine strategies that could be implemented to avoid vaccine-related problems in naive birds. Some authors recommend individual vaccination as a safer alternative to guarantee a homogenous protection, but this measure is restricted by its high costs. Alternatively, use of high passage attenuated vaccines to develop an initial immunity level could prevent outcome of clinical signs.

In conclusion, we characterized two IBDV isolates from layer chicken flocks in the state of Minas Gerais. The flocks presented clinical signs characteristic of the IBD at 3 and 11 days after the vaccinal boost using an intermediate plus vaccine.

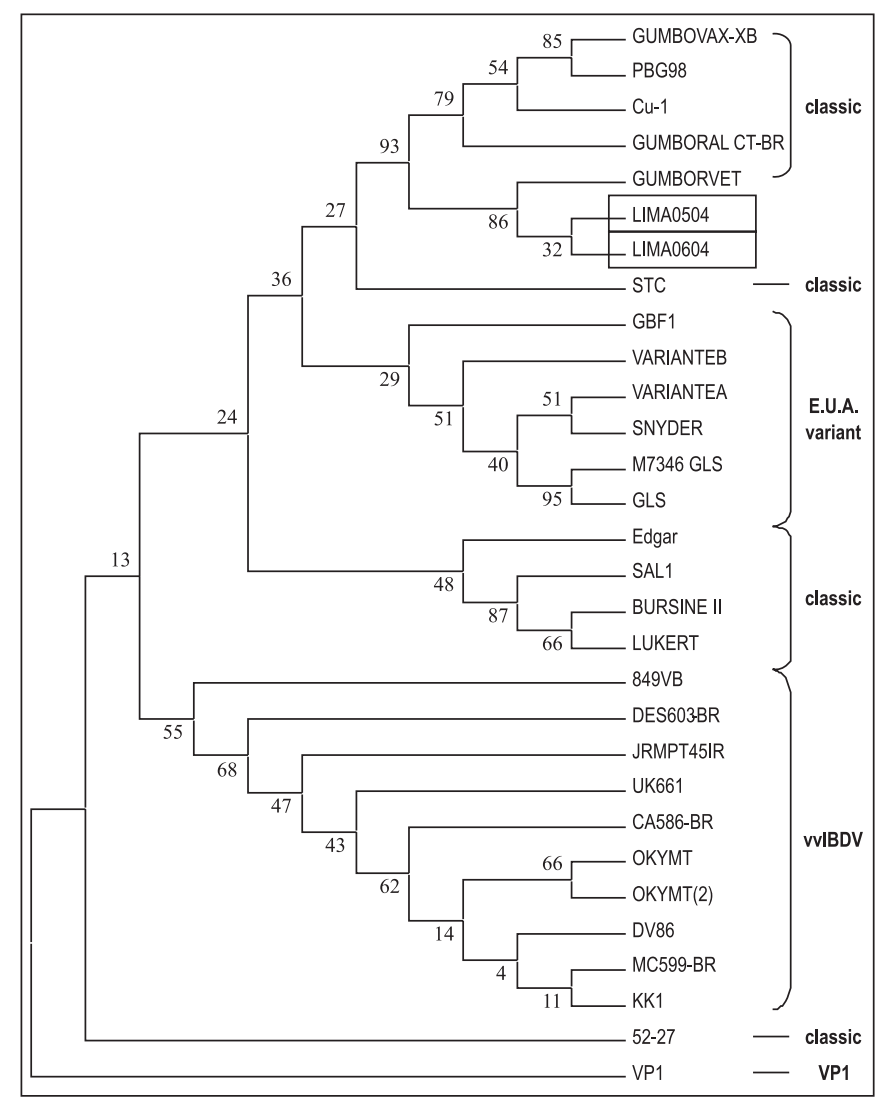

Figure 1. Phylogenic tree based on the VP2 hypervariable region (nucleotide positions 842 to 1053; numbering according to Bayliss et al., 1990) of IBDV isolates. Localization of LIMA0504 and LIMA0604 isolates are noted. Tree was constructed by Neighbor-Joining method with the Kimura model (1980). Bootstrap probabilities are given beside the node.

Histopathology of the bursa associated to clinical signs indicated that the disease was caused by IBDV. The molecular data indicates that these viruses are the same classic strain utilized to produce vaccines. Monitoring chicken flocks for pathogenic IBDV is crucial and molecular methods can be used to identify and characterize the agent for improving vaccination programs and vaccine choice.

\section{RESUMO}

\section{Sequenciamento e análise filogenética de isolados do vírus da doença infecciosa bursal de surtos ocorridos em lotes de poedeiras no estado de Minas Gerais}

O sequenciamento e a análise filogenética a partir da seqüência nucleotídica do gene que codifica a proteína VP2 foram realizados com o intuito de caracterizar os agentes 
238

256

LIMA0 504 TSLSVGGELVFOTSVHGLVLGATIYLIGFDGTAVITRAVAANNGLTTGTDNLLPFNI LIMA0 604 TSLSVGGELVFQTSVHGLVLGATIYLIGFDGTAVITRAVAANNGLTTGTDNLLPFNI

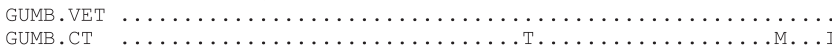

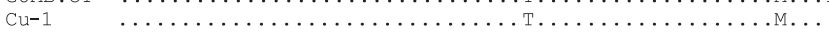

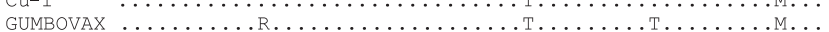

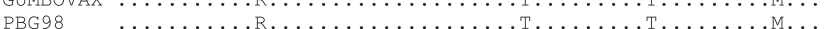

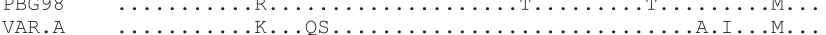

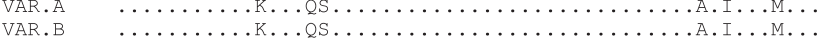

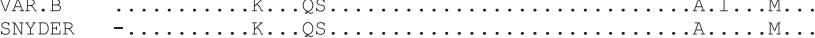

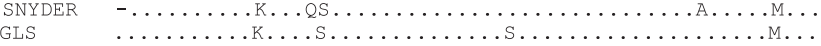

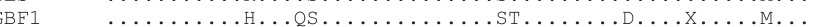
MC599-BR $-\ldots I \ldots \ldots \ldots \ldots$ I. I.....................

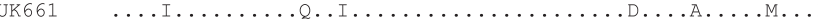
CA586-BR ...I............................

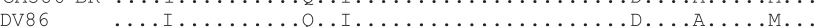

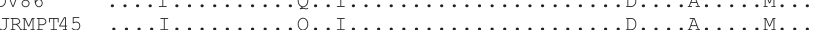

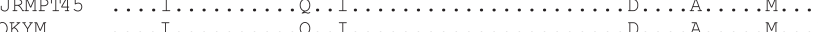

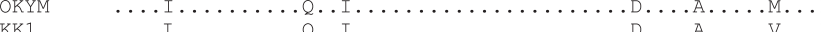

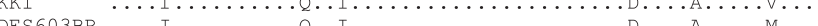

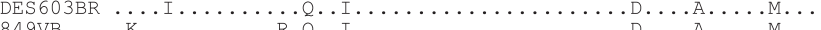
S49

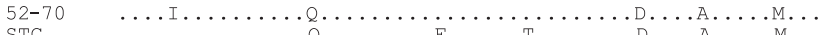

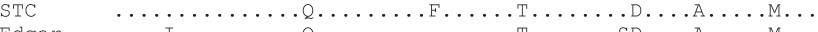

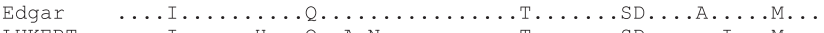
LUKERT $\quad \ldots$ I............N......................... BURSINE2 $\ldots$ I...................................... SAL1 $\quad$.........T.PC.A.D......................

LIMA0504 VIPTNEITQPIT LIMA0604 VIPTNEITQPIT

LUMB.VET $\ldots \ldots \ldots \ldots$. . .

GUMB.VET $\quad \cdots \cdots \cdots \cdots$

$\begin{array}{ll}\text { GUMB. CT } & \ldots \ldots \cdots \cdots \\ \mathrm{Cu}-1 & \ldots \mathrm{S} \ldots \ldots\end{array}$

$\begin{array}{lll}\mathrm{Cu}-1 & \ldots \mathrm{S} \ldots \ldots \ldots \\ \text { GUMBOVAX } & \ldots \ldots \ldots \ldots\end{array}$

PBG98 $\quad \cdots \cdots \cdots \cdots$

VAR.A $\quad \cdots \cdots \cdots \cdots$

VAR.B $\quad \cdots \cdots \cdots+\cdots$

SNYDER $\quad \ldots \ldots \ldots \ldots$

GLS $\quad \ldots \ldots \ldots \ldots$

GBE1 ...............

MC599-BR …S........

UK661

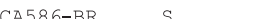

DV86 BR ……....

DV86 …….....

JRMPT45 $\cdots$.

OKYM $\quad \cdots . . . . . .$.

KK1 $\quad \ldots$. . . . . .

DES603BR $\ldots \cdots \cdots \cdots$

849VB $\quad \ldots \ldots \ldots \ldots$

$52-70 \quad \ldots \ldots \ldots \ldots$

STC $\quad \ldots \ldots \ldots \ldots$

Edgar $\quad \cdots \cdots \cdots$

UKERT $\cdots \cdots \cdots \cdots$

SAI $1=\ldots . . . . . .$.

Figure 2. Alignment and comparison of deduced amino acid sequence (238 a 306; numbering according to Bayliss et al., 1990) of the VP2 hypervariable region of IBDV isolates. Amino acid differences related to the LIMA504 and LIMA0604 isolates are shown, and identical amino acid residue is indicated with a dot. causadores de dois surtos da doença infecciosa bursal em lotes de poedeiras do estado Minas Gerais, em 2004. Os resultados indicam que os surtos analisados podem estar relacionados com o vírus de origem vacinal.

Palavras-chave: IBDV, RT-PCR, caracterização molecular, análise filogenética, doença infecciosa bursal.

\section{REFERENCES}

1. Bayliss, C.D.; Spies, U.; Shaw, K.; Peters, R.W.; Papageorgiou, A.; Muller, H.; Boursnell, M.E.G. (1990). A comparison of the sequences of segment A of four infectious bursal disease virus strains and identification of a variable region in VP2. J. Gen. Virol. 71 (6), 1303-1312.

2. Boot, H.J.; Ter Huurne, A.A.H.M.; Peeters, B.P.H. (2000) Generation of full-length cDNA of the two genomic dsRNA segments of Infectious Bursal Disease virus. J. Virol. Methods 84 (1), 49-58.

3. Ikuta, N.; El-Attrache, J.; Villegas, P.; Garcia, E.M.; Lunge, V.R.; Fonseca, A.S.; Oliveira, C.; Marques, E.K. (2001). Molecular characterization of Brazilian infectious bursal disease viruses. Avian Dis. 45 (2), 297-306.

4. Jackwood, D.; Sommer-Wagner, S. (2007). Genetic characteristics of infectious bursal disease viruses from four continents. Virology 365 (2), 369-375.

5. Kimura, M. (1980). A simple method for estimating evolutionary rates of base substitutions through comparative studies of nucleotide sequences. J. Mol. Evol. 16 (2), 111-120.

6. Liu, H.J.; Huang, P.H.; Wu, Y.H.; Lin, M.Y.; Liao, M.H. (2001). Molecular characterization of very virulent infectious bursal disease viruses in Taiwan. Res.Vet. Sci., 70 (2), 139-147.

7. Majó, N.; El-Attrache, J.; Banda, A.; Villegas, O.; Ramis, A.; Pagès, A.; Ikuta, N. (2002). Molecular characterization of Spanish infectious bursal disease virus field isolates. Avian Dis. 46 (4), 856-868.

8. Nagarajan, M.M.; Kibenge, F.S.B. (1997). Infectious bursal disease virus. A review of molecular basis for variations in antigenicity and virulence. Can. J. Vet. Res. 61 (1), 81-88.

9. Sharma, J.M.; Kim I.J.; Rautenschlein, S.; Yeh, H.Y. (2000). Infectious bursal disease virus of chickens: pathogenesis and immunosuppression. Dev. Comp. Immunol. 24 (2), 223-235.

10. Sreedevi, B.; LeFever, 1.J.; Sommer-Wagner, S.E.; Jackwood, D.J. (2007). Characterization of infectious bursal disease viruses from four layer flocks in the United States. Avian Dis. 51 (4), 845-850. 